\title{
HOW CAN A RURAL AREA DRIVE THE NETWORKING OF EXISTING BUSINESSES WITH IT SUPPORT?
}

Elvira KUHN, Institute of Business Informatics, Faculty of Economy, University of Applied Sciences Trier, Schneidershof, 54293 Trier, Germany; e.kuhn@ @ochschule-trier.de (corresponding author) Hertbert KÜSTNER, Café PALAVER, Address: Hermeskeilerstr.26, 54320 Waldrach, Germany; herbertwaldrach@gmx.de

In order to be innovative in a rural area, it is necessary to act in an extraordinarily cooperative fashion, partly because the people living there know each other well, but also because they want to remain there, share their lives with the neighbours and do not simply change homes to start fresh in another part of town, as it happens in larger cities. The appropriate support of informational management regarding cooperative behaviour is in the focus of this paper. Our selection of research methods includes the execution of study projects to the subjects of innovation, It- and Information Management for an cooperative network, the development of an app to encourage young people to stay in the pertaining village, to the publishing of four books concerning communication and cooperation on the basis of original research, surveys, discussions with residents, meetings with the management of small enterprises as well as with the administration and colleagues of universities and the evaluation of the collected data through statistical methods and processes. We have found that the introduction of regular meetings of a variety of people with the task to think about new ideas and to decide on which one will be realized first, to give support in different ways before, during and after the project conclusion in combination with suitable Information Management is able to reduce the fear of digitalization and bind the focused power of concentration to the project. In conclusion we find that it is possible to augment the communal mind set to be innovative and creative in order to make rural living more pleasant.

Keywords: Cooperative network, Innovations, Information Management, self-realization, share community.

\section{INTRODUCTION}

There are many small businesses in rural areas, run by family dynasties and ensuring the survival of families. A life in riches and luxury is not the goal in this case, only subsistence and communal living. It is often seasonal work that governs alternatingly production time-tables and sales, for example in agriculture and viniculture, but also in the creating and selling of Christmas wreaths, Easter decorations or leather products with the usage of exclusively natural products, including buttons made from horn. Services such as senior citizen care, hairdressers, and masseurs will be just as responsible as the smaller and medium sized businesses and the administration for Corporate Social Responsibility (CSR). They often support associations through small gifts or consider independently from each other with what kinds of services best to support associations or public institutions. The combination of the small drops to one powerful, guided stream might provide new and exciting possibilities. Communal societies in the form of trusts, associations and agencies have been created in some villages already, representing the public's special interests or offer support when decisions have to be made. For example, there is an energy agency in the Eifel that optimizes investments concerning energy issues at home and at business sites. The questions is how synergies can be improved in order to create innovative surroundings in rural areas. This includes the identification and eradication of hurdles hindering the development towards a more common activity of enterprise. All participants shall still be excited about their ideas and projects, and be able to realize them. If all of them feel more deeply connected, a cooperative and trusting environment will be the result, with open and fair interactions and the possibility to conquer new realms of creativity. This leads to the establishment of a cooperative network as a research goal, to improve the rate of innovation in rural areas, as well as to create and secure jobs.

\section{RESEARCH METHODS}

To identify possible obstacles for the establishment of cooperative networks, we select the realization of study projects including the presentation and discussion of the results as our primary research method. This will not only ensure an intense literature research, but also the lively debate of the subject from different points of view. The scope of subjects includes the design of an innovation friendly environment at an university (Becker, 2019) with the main target of being a motor for the region, the subject of IT - and Information Management for a cooperative network and the securing of the infrastructure necessary for the area's survival. The following ideas were the foundation for our selection process:

Studies and discussions about innovative environments 
If we follow our main objective for a university - to be the motor for the region - it should be possible to communicate our findings sustainably and concisely to the region. To achieve this, such an innovation friendly environment has to be build first (see more in (Wojda, 2006)). It should also function as a civic platform enabling the exchange of creative ideas, which in turn shall be led to realization, actualization and further innovation through the support of scientific, financial and pertinent help. Through well-established knowledge concerning the state of the art by way of extensive research and original thoughts hidden opinions and desires shall be brought to light in discussions and questionnaire surveys, as well as direct live interviews. All of the hereby gathered results shall serf the purpose of gaining a better understanding on what constitutes a successful approach to interdisciplinary cooperation between diverse fields of knowledge, companies, external organizations and students.

Studies about IT - and Information Management for a cooperative network

The main objective of these studies was to discern whether or not and how the extant companies can be brought towards a deeper connection through the support of IT in a rural area. It is the initial state in the Eifel, that new start-up companies are founded regularly, some established companies prevail while others are being terminated. It is common knowledge that traditions disappear, along with the often connected sense of home, as surveys among locals have shown. Further problems and hindrances shall be analysed and transferred into a target system. The Fish-Bone-technic was the primary method of problem analysis. Methods and procedures such as HIPO-VTOC, classification and segmentation principles as well as Jacobson-procedures for process creation, (Balzert, 1997). BPMN, UML's Use-case-diagrams, process diagrams, interaction diagrams, activity diagrams were used for the identification and presentation of informational flows between participating actors and processes. All methods are described in (Balzert, 2009). Other tasks were the discussion of concepts of synergy and cooperation, as well as considerations regarding ideal strategies towards improved cooperation. Hereby, the principle of aspect separation was employed. Since the exchange of information, but also collaboration and communication in the age of digitalization (Kuhn 2018) suggest the use of a platform, a fair information spread and its control had to be considered just as much as methods of engagement and the carrying of full responsibility. In the end, the subject of IT security and the connected field of awareness rising of participating actor in the network were tackled. Video clips and tutorials were created in favour of a better understanding of the material. The same manner of approach was used with the matter of data security and the related involvement of EU-law, with the content of cooperation contracts and data protection mandates, which had to be created by companies and their employees. To have financial and subsidising options available if needed, the researched results should be structured and made ready to be found by keywords. The structuring principle of the classification was reused for this. The tasks needed in the administration of a cooperation platform shall be presented in workflows and the roles be described according to the standardised V-XT-model (BVA 2010).

Studies about securing the infrastructure necessary for sustaining life.

These studies were conducted with the aspect of organisation with antifragile project management (Kuhn, 2019, Lorenz 2019, Taleb 2012) in mind. These studies are carried out under the aspect of organization by means of an antifragile project management. Initially, the topic No infrastructure in or to a village is subdivided into the sub-topic Organization of an E-car sharing system in rural areas and into the sub-topic Organization of securing goods of vital importance. A further subdivision into single problems follows, allowing for a useable and ready solution to each one of them. Each project partner works at first individually at their pertaining problem field. Whoever finds their solution first, helps the one furthest away from theirs etc. The objective is to name the problem within the hour, including the beginnings and ends of the tasks at hand. The workflow, the process of upcoming tasks, is the result. The goal is to dissect possible workflows concerning the matter of different organisational forms. At the end, a precise recommendation for the best organisational form solving the individual problem can be given.

\section{Creation of App}

Furthermore, an App was created in the context of a lecture dealing with problem and requirement analysis up to requirement specification. The district administration Trier asked for this App. It should serve the purpose of keeping young people in their villages and lower the high fluctuation rate. The procedure, methods and techniques adhered to IEEE1471-Standard (IEEE 1471, 2000). Most importantly, concrete measures were to be established to achieve the main goal of improving life in the pertaining rural area. Structured Analysis was the method used to define the functions. The agile approach Scrum was employed for the project management. Several programming environments were tested for the phone application. Eclipse proved to be as insufficient as the allegedly free websites LIVECode (Tappel, 2016) and CLICKYourAPP (YouTube, 2016). A HTMIL-App that can be read by any smartphone was the result. A link behind an Icon functions as a start button. Another way of starting it is by the provided QR-Code.

Workshops

The different workshops for interested citizens and members of associations, for example one propagating the establishment of e-carsharing in rural areas, or one concerned with the changes in behaviour induced by digitalization were conducted in the form of World Café Etiquette tables as described in (World Café Method....2019). This process involves the creation of different specialised questions for each table. To come back to the aforementioned workshop: What are good marketing strategies for an e-car sharing system in one's own place, as well as the Vulkaneifel? These are considered by the citizens seated at the table under the guidance of a mentor. Results are noted on the tablecloth. After about 20 minutes, important findings and ideas are being comprised, in our case written on cards that were pinned to the walls. Then, the guests rotate to the next table, the mentor introduces the results to the new arrivals. When every guest has visited each table, the final results are presented to everyone and new group meetings are planned.

Books 
Contributions to books were based on term papers dealing with the subjects of communication and cooperation. They used original research as well as surveys and discussions. Desires and mind-sets of locals in rural areas were gathered in meetings with management of small enterprises as well as with the administration and colleagues from universities. The evaluation of the collected data was accomplished by using statistical procedures. To clarify the needs of the citizens from their point of view, at first the problems at hand that could pose an extraordinary hindrance to the cooperation of small and medium sized companies were defined commonly. These have to be dealt with immediately, in order to form an innovative environment.

\section{RESULTS}

Guided by the results from the different types of study projects, it is possible to create a general concept for a cooperative network and finally transfer the findings into a job posting for an informational manager (IM).

Conception of an IT platform and the pertaining IM

This IM functions as a caretaker in financial troubles, as an organizer of meetings for people interested in the realization of an idea and as support for the risk management. The IM stand ready to help out during conflicts, settles fears and erases blockades and improves the range of new technologies in the IT-sector (read more in Implementation of ...2019). Because of the many different areas of expertise at a university, solutions can be found across diverse subjects. Therefore it makes sense, to create the IM position at a university. Additionally, a university is a place of scientific and artistic work. The broad range of possible courses at a university offers an ideal creative environment and offers, in combination with a state-of-the-art infrastructure and well equipped facilities, the chance to learn and research to everyone. Options for further education are here being made possible, both from a scientific and business perspective. Also, senior consultants (professors practising and emeritus) share their knowledge, experience and contacts from the start of the CN. Students are being offered interesting subject for Bachelor and Master Theses. Therefore, the CN is a source of new innovations and subjects. The CN's support can also be helpful when conducting research and analysing data from surveys. To secure a fair treatment of one another, guidelines have to be established. The use of synergies and the realization of current tasks is ensured directly by the reciprocal exchange of knowledge and needs. In the age of digitalization, antifragile acting needs to be the guiding principle: It is important to react quickly to new developments and reposition oneself accordingly in a constantly changing environment. Antifragile enterprises manage to reduce the damage in cases of failure to a minimal level. At the same time, they maximize profits when succeeding. Safety cushions help in achieving these goals (see more in (Taleb, 2012).). An open exchange of knowledge and information between all parties provides a new climate of cooperation. The IM ensures a fair commerce with the findings by realizing the established guidelines. The $\mathrm{CN}$ also enables, supports and advances projects and enterprises as cooperation between research and teaching, administration and business in a long term perspective. Hereby the IM functions as a caretaker to ensure continuity, especially as a person who takes on comprehensive tasks surpassing individual groups and ensures their realization. Through this, the university also adheres to the principles of Corporate Social Responsibility (CSR) and helps an entire region to implement them. Tasks of CSR (Corporate Social Response) are being made actionable. Thirdparty funds facilitate the creation of a centre for digitalization as a gateway between IT, informational management and the involved actors. The hereby achieved win-win-situations promote the university's reputation long-term, facilitate companies' exchange of and access to employees and also improve the realization of digitalization processes in the administration of municipalities. They bring education to the rural areas through schools, invoke a greater pleasure to learn and to teach, especially through a creative space in which to realize themselves, but also to promote the ability to cooperate. Cooperation means a purposeful cooperation of the participants of the $\mathrm{CN}$ to increase the common competitiveness according to guidelines. This refers to the exchange of information, experiences and agreements, up to the formation of a joint cooperation management. Connected to each other, instead of working against one another cooperation as a leitmotif - bottom up instead of top down, promoting a closeness to citizens, acceptance and scope of actions. It is possible for everyone to contribute in some way: donations of money to the projects, support in work time or offering material contributions for free, possibilities of support through the close contacts to the administrations and, by the professors, the new possible impulses of thinking at the university.

\section{IT - Security - Training Concept / Sensitization - Public Relations}

The results of the use of a concrete platform as well as the tasks have been presented to the public, not only in the form of lectures and discussions, but also in various media outlets. Publications have been published in magazines such as CAMPINO of the University of Applied Sciences in Trier (Kuhn E., Küstner H. 2019). The Department of Public Relations at the university has sent the report on CN's findings to over 80 different forums and companies. Under (Handouts...2019), the handouts of the presented strategies in the IM, as well as guidelines for data protection and data security are available. The feedback is excellent. For youth centres or supervisors for young people, the necessary information can be found there in a colloquial, easy-to-understand way. Other institutions and associations have asked for permission to use it. An interview on the topic was conducted by CITY Radio Trier and broadcast several times on the radio (27.02 and 2.03 2019, two times each day). This ensures that a broad population learns more about the concept. Studies about ensuring the necessary infrastructure for the preservation of life.

At the moment, the Ministry offers a great deal of funding for the creative and cultural industries (Wissing 2019). However, it is not necessarily the equipment required to practice the arts, but rather the necessary infrastructure or economic knowledge such as marketing. Also, many locals in the village do not have the resources to buy works of art, and sometimes even the bare necessities to survive. For example, the students dealt with the topics of infrastructure in a 
place to ensure the supply system of a village, customer acquisition and placement of professional contacts and the organization of an e-car sharing system in rural areas from an organizational point of view. Figure 1 shows the process of identifying various work packages dealing with the need to satisfy residents on the subject of ensuring the supply system of a village.

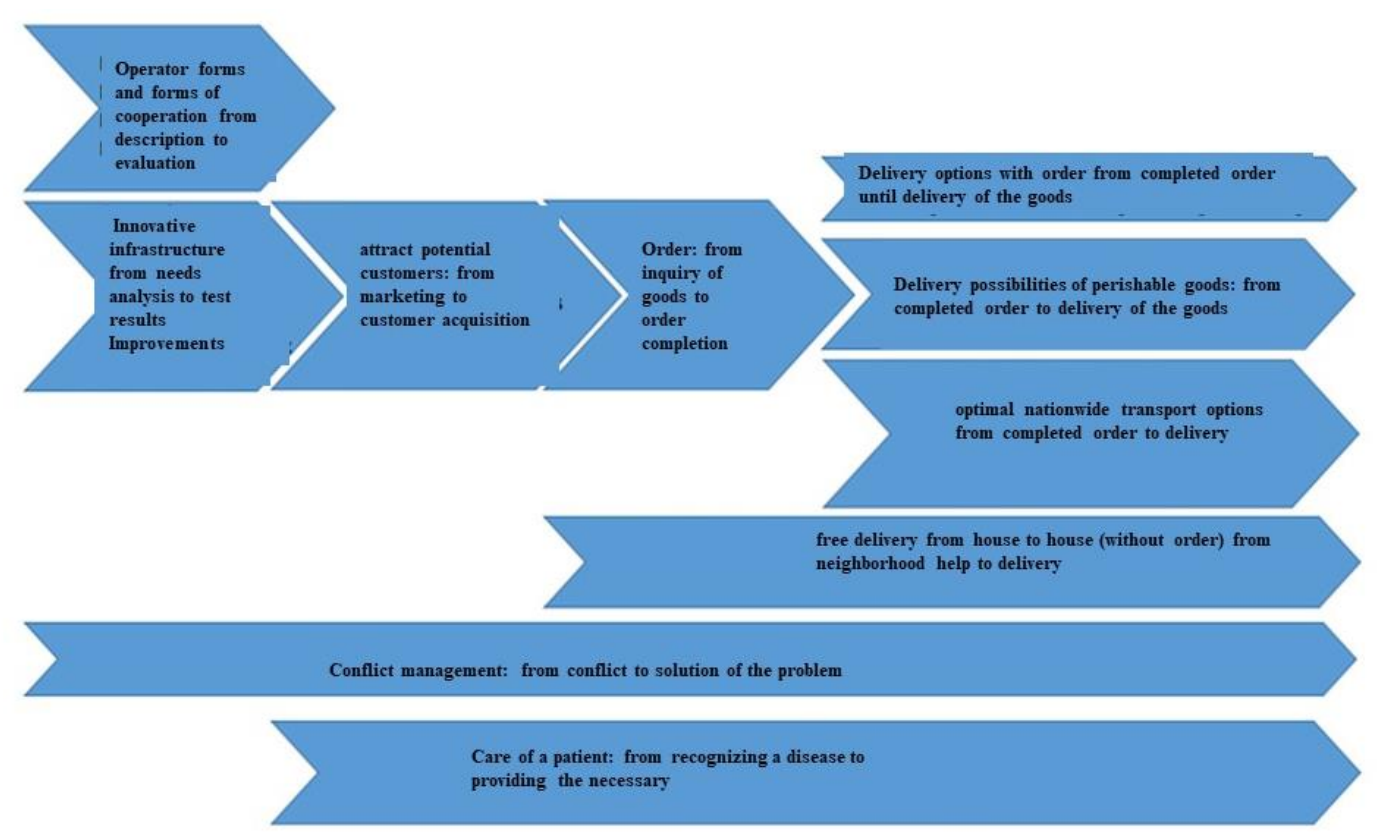

Figure 1. Supply system of a village

Each of these topics was then examined for different forms of organization and implemented in the form of workflows using workflow management. After that, a statement can be made as to what is the fastest and best way for the implementation to be guaranteed. The associated role descriptions give an overall picture of the required skills and responsibilities for handling the tasks involved. Thus, a feasibility analysis can more easily be prepared.

Development of an app to prevent the rural exodus of young people

Having ideas and implementing them is the basis for innovation. Especially adolescents with their creative ideas and willingness to experiment need to find more support, according to the results of the adolescents' survey. Especially in the areas of culture, politics and mobility young people should not be "left behind". Spontaneous meetings are just as supportive as professional youth work or training. The question of financial, spatial, technical or material support arises from the social responsibility (Corporate Social Responsibility / CSR) of companies, universities and administration with the involvement of citizens, which is demanded across the EU. Interesting topics for young people are leisure time, CSR / CRM, politics, informational infrastructure, communication, cooperation, coordination and collaboration, data protection and data security. As a result, it has to be noted that the curiosity and creativity of young people must be promoted, that the will for further education and mutual assistance needs support, but also that young people as citizens must also be taken seriously. As noted in (Kuhn, Küstner, 2019), but certainly not only here, it is necessary to meet the demands or expectations of young people, but conversely to communicate the expactation to them of engaging themselves in the community. Professionals such as in IT, music and sports equipment can provide young people with access to the latest technology. Figure 2 shows some surfaces of the APP for teens:
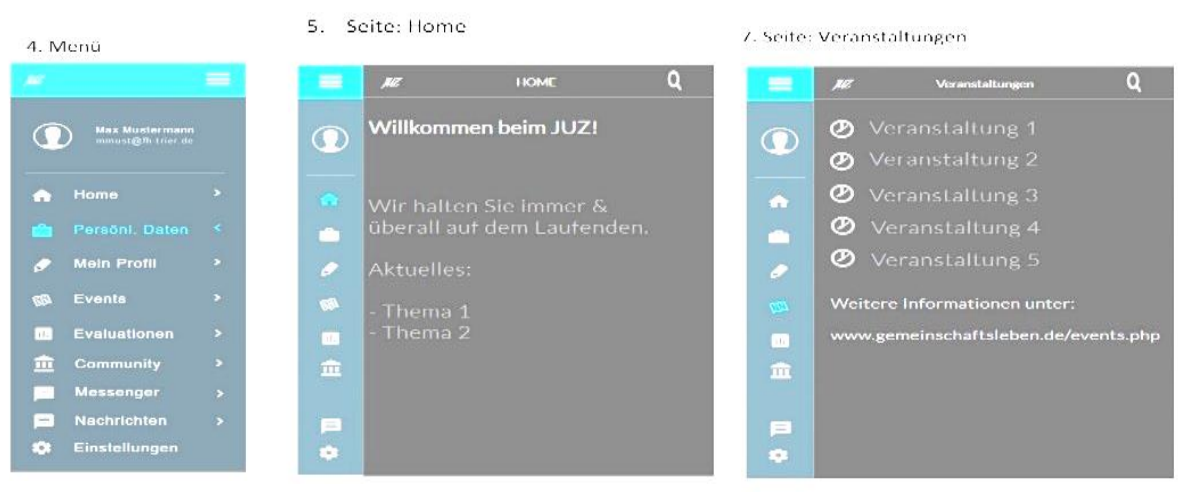

Figure 2. Some Surfaces of the APP JUZ after Registration 
We are able to reproduce the concept that people in the village know each other and know where to rent a device. We allow people search or offer the equipment they want to lend and borrow, and the distributor can arrange it individually.

Workshops

Workshops are a very efficient way to help those interested in a topic, to involve them, to get to know their interests and to learn something new from them. It has been shown that there is a lot of know-how and willingness to contribute a lot of information for everyone's benefit. Finally, all participants wanted to continue working in special working groups. Thus, a subset of the edited topics for the introduction of an e-car sharing system by a citizen association was presented by the students. Figure 3 shows the complete overview of the edited topics:
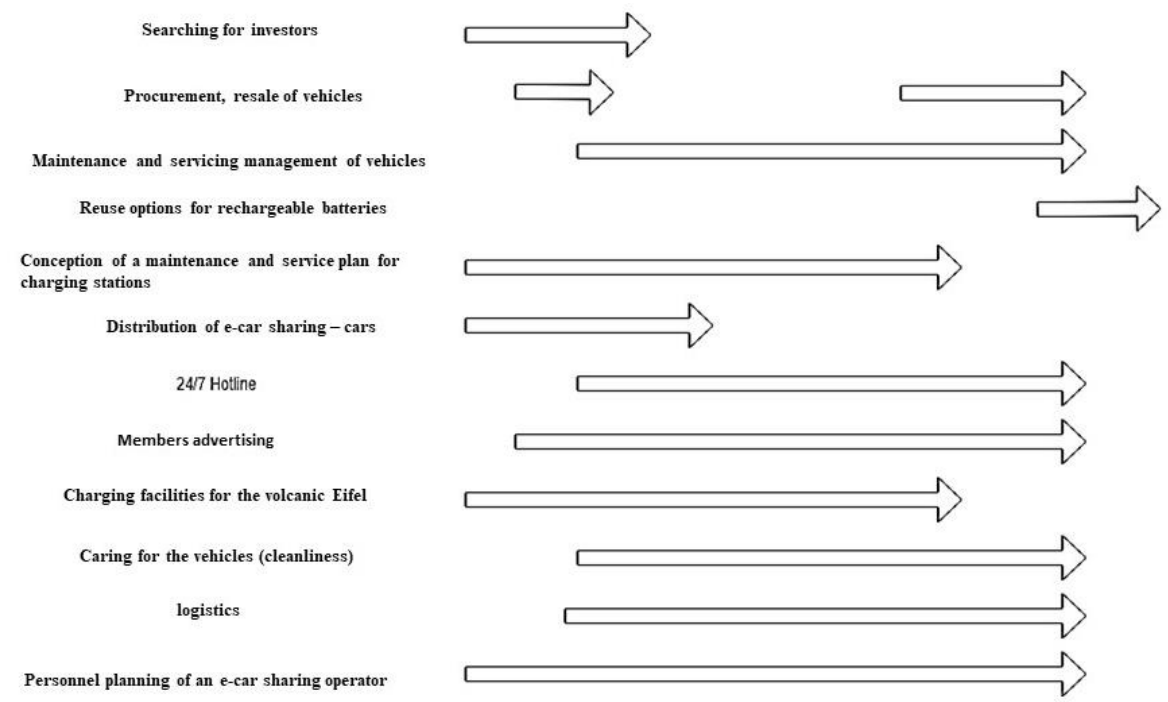

Figure 3. Overview of the introduction of an e-car sharing system by a civic association

The 5 selected topics everyday rides, taking care of the cars, marketing, locations of the charging stations and locations of e-car sharing are now further processed in the working groups. It has been shown that the interested parties can be brought together by a caretaker, furthermore that platforms for exchange can be formed and thus innovation can be promoted. With a solid preparation of pertaining knowledge on environmental conditions in a problem area, barriers are reduced. A good atmosphere does its part to help.

Surveys

From our discussions, direct surveys or via questionnaire actions, we can determine the desire for coexistence and joint research at the University, both with the professors and with the students. The momentary deficit lies in the inability to communicate and exchange ideas in order to create synergies. Discussions about an innovation process and the problems lead to the following results:

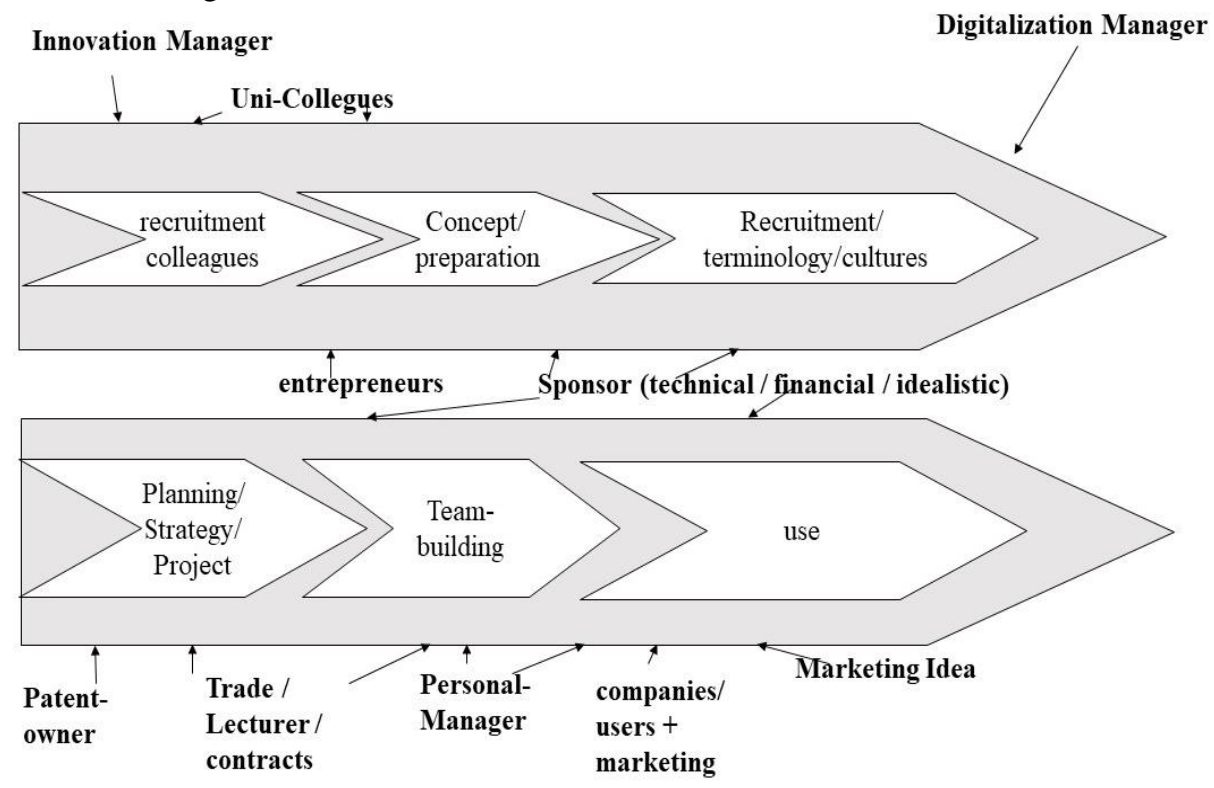

Figure 4 Innovation process with interdisciplinary work

As shown in figure 4, according to our considerations, an innovation process consists of the sub-processes recruitment of colleagues (e.g. including professors from other universities), conception and preparation of the project, 
recruitment of project participants, planning and development of a strategy for the project, team building, as well as implementation and usage of the original idea. The innovation manager, the employer, market and legal aspects and the digitization manager are examples of influence on this process. Innovations at the University of Trier are mainly created in interdisciplinary cooperations. Therefore, this area should be supported by IT measures, such as a common platform for efficient and modern room and laboratory assignment, as this is the only way to simplify the cooperation of the different areas and to further promote innovative work. A reserved lunch table exclusively for the professors allows for discussions and inspirations in a casual atmosphere.

Studies in published works

To live knowledge management exemplifyingly means to spread knowledge. This includes writing books whose advantage it is to deal intensively with professional terms and state of the art. As you can read in (Implementation of .....2019) the co-author has a critical look at the topic of a useful IT strategy in a cooperative network. The result is that "to invigorate the changing processes to gain cooperation on workplaces, a new enterprise culture will have to follow. The impact on human beings, is that the employees decide on how much they want to participate. Finally, the impact on society is happiness and therefore an improved health and better quality of life." It is necessary to analyse the problems and obstacles to cooperative work. So the knowledge on communication management is important. In (Happ 2016) requirements for the handling of information are therefore fleshed out. Thus, we discuss the company's internal communication and its understanding of form and function thereof, the topics influence and optimization possibilities of communication. Above all, the use of words or techniques in situations such as introducing innovations, having existential fears as well as high degree of innovation (impact on work very high) to the topic of the different communication techniques and their applications is discussed as well as the consideration of what will probably be possible in the future. The second book (Kücüköz, Kuhn, 2018) examines more closely the requirements for dealing with information and examines influencing factors such as stress and emotions, as well as casting a closer look at technical innovation psychologically, especially in the last chapter, the technological possibilities of distorting information. As a result, internal communication is in a state of flux. The third book (Diethelm, 2018) deals with the impact of digitalization on the organization and success of an enterprise. It addresses the end of privacy versus economy, changes in consumer behaviour, and the question of whether the digital manager will be a human or a machine. Finally, limits and revision of digitalization are examined. Book number 4 (Ehl 2019) discusses cooperation management, network management, corporate culture and error management. By dealing with the terms communication and cooperation, the necessary management of a cooperative network and the skills of an information manager can be determined. As a result, it should be noted that a digital information and coordination system is able to support cooperation between universities, colleagues, administrations and companies with adapted information management in the network. Sustainable development in an IT network can only be ensured if someone considers which new IT laws have to be complied with and implements them, and if someone takes care of sources of error or of new developments in the IT sector. Since an IT infrastructure is part of a virtual world, on the one hand the savings potential of no longer traveling by car and thus reducing the need of road expansion and additional transport infrastructure are given, but on the other hand there is an increased need for information superhighways. Even with the participation of citizens in the development of the bio-economy, a $\mathrm{CN}$ is indispensable.

\section{Overview of the main results}

We designed the creative environment needed for innovation and analysed the necessary process, we described the $\mathrm{CN}$ and the IM, so that there is the possibility of intensifying the communication exchange, mutual learning creates the possibility of cooperation, and concrete infrastructure approaches such as the goods important for sustaining life or to support E-car sharing were fully functional. With an app, we provided an improved community life. Obstacles such as a lack of infrastructure, lack of trust and lack of entertainment during leisure time were compensated. This strengthens the community. As a side effect, jobs are created by forming or maintaining more start-ups with the support of a CN, a pending acquisition of an existing company is communicated more quickly, specialised schools tend to find more participants in art, culture, music and other classes.

Table 1 shows the solution and their effects on infrastructures, social competence and economy. These three points are addressed by Bio-economy as seen in (BMBF Bioeconomy, 2019).

Table 1. Problems and Solutions with their effects

\begin{tabular}{|c|c|c|c|}
\hline Problem & Missing infrastructure & Social competence & industry and commerce \\
\hline Carsharing & Free or rent cars & Is funded & Is funded \\
\hline $\mathrm{CN}$ & Virtual and real world & Is funded & Is funded \\
\hline $\begin{array}{l}\text { Getting things on demand/ } \\
\text { Neighbour/ } \\
\text { community }\end{array}$ & $\begin{array}{l}\text { Order through the net (with) } \\
\text { / Neighbourhoods help / }\end{array}$ & Partially funded & $\begin{array}{l}\text { Collecting orders }- \text { having } \\
\text { more orders }\end{array}$ \\
\hline
\end{tabular}

As you can see in table 2, our concept gains most of the wished effects. By example, to use fewer cars will lead to a decrease of investment less money in infrastructures as parking places or roads. More communication leads to a better understanding of one another and to act in the right manner in the sense of protection of the environment. Cooperation and collaboration with each other lead to more possibilities of recycling. But as you can see to use the CN by G5 there is the need of a very competent IM to gain the desired results. Not simply the arbitrary use at any time is constructive, but the purposeful use of technologies, resources and materials. 
Tab: 2 Solutions and their effects on Environment, Society and profit

\begin{tabular}{|c|c|c|c|c|c|c|c|c|c|}
\hline \multirow[t]{2}{*}{ Support } & \multirow[t]{2}{*}{ Effects } & \multicolumn{2}{|c|}{ Environment } & \multicolumn{2}{|l|}{ Society } & \multicolumn{4}{|c|}{ Profit } \\
\hline & & \multirow{2}{*}{$\begin{array}{l}\text { wished } \\
\text { Less } \\
\text { environ- } \\
\text { mental } \\
\text { damage } \\
\end{array}$} & \multirow{2}{*}{$\begin{array}{l}\text { gained } \\
\text { less } \\
\text { environ- } \\
\text { mental } \\
\text { damage } \\
\end{array}$} & \multirow{2}{*}{$\begin{array}{l}\text { wished } \\
-\end{array}$} & \multirow{2}{*}{$\begin{array}{l}\text { gained } \\
\text { More time } \\
\text { needed }\end{array}$} & \multicolumn{2}{|l|}{ private } & \multicolumn{2}{|l|}{ enterprises } \\
\hline Cars & & & & & & yes & yes & $\begin{array}{l}\text { Better life } \\
\text { for team }\end{array}$ & $\begin{array}{l}\text { More } \\
\text { money } \\
\text { needed }\end{array}$ \\
\hline $\begin{array}{l}\text { radiation } \\
\text { (G5) }\end{array}$ & exposure & less & $\begin{array}{l}\text { More } \\
\text { high by } \\
\text { bad } \\
\text { Mana- } \\
\text { gement }\end{array}$ & healthy & $\begin{array}{l}\text { Danger by } \\
\text { bad Mana- } \\
\text { gement }\end{array}$ & - & - & - & $\begin{array}{l}\text { Danger by } \\
\text { bad Mana- } \\
\text { gement }\end{array}$ \\
\hline $\begin{array}{l}\text { Direct } \\
\text { Communi }\end{array}$ & ation & $\begin{array}{l}\text { Under- } \\
\text { standing, } \\
\text { handling }\end{array}$ & $\begin{array}{l}\text { Under- } \\
\text { standing, } \\
\text { handling }\end{array}$ & better & better & - & - & - & - \\
\hline $\begin{array}{l}\text { Virtual } \\
\text { Communi }\end{array}$ & cation & $\begin{array}{l}\text { Under- } \\
\text { standing, } \\
\text { handling }\end{array}$ & $\begin{array}{l}\text { Under- } \\
\text { standing, } \\
\text { handling }\end{array}$ & better & better & More high & More high & More high & More high \\
\hline Collabora & & - & $\begin{array}{l}\text { More } \\
\text { recycling }\end{array}$ & $\begin{array}{l}\text { Better } \\
\text { utilisa-tion } \\
\text { of } \\
\text { materials }\end{array}$ & $\begin{array}{l}\text { Better } \\
\text { utilisa-tion } \\
\text { of } \\
\text { materials }\end{array}$ & $\begin{array}{l}\text { Better } \\
\text { utilisa-tion } \\
\text { of } \\
\text { materials }\end{array}$ & $\begin{array}{l}\text { Better } \\
\text { utilisa-tion } \\
\text { of } \\
\text { materials }\end{array}$ & $\begin{array}{l}\text { Better } \\
\text { utilisa-tion } \\
\text { of } \\
\text { materials }\end{array}$ & $\begin{array}{l}\text { More } \\
\text { time, more } \\
\text { money }\end{array}$ \\
\hline Cooperati & & - & recycling & - & $\begin{array}{l}\text { Higher } \\
\text { trust }\end{array}$ & $\begin{array}{l}\text { More } \\
\text { working } \\
\text { places }\end{array}$ & $\begin{array}{l}\text { More } \\
\text { working } \\
\text { places }\end{array}$ & $\begin{array}{l}\text { More } \\
\text { working } \\
\text { places }\end{array}$ & $\begin{array}{l}\text { More wor- } \\
\text { king } \\
\text { places }\end{array}$ \\
\hline Share-Cor & imunity & $\begin{array}{l}\text { Less } \\
\text { degra- } \\
\text { dation of } \\
\text { rare } \\
\text { earths }\end{array}$ & $\begin{array}{l}\text { Less } \\
\text { degra- } \\
\text { dation of } \\
\text { rare } \\
\text { earths }\end{array}$ & $\begin{array}{l}\text { Enough } \\
\text { water }\end{array}$ & $\begin{array}{l}\text { Enough } \\
\text { water, get } \\
\text { together, } \\
\text { higher } \\
\text { common } \\
\text { unit }\end{array}$ & $\begin{array}{l}\text { Less } \\
\text { money }\end{array}$ & $\begin{array}{l}\text { Less } \\
\text { money }\end{array}$ & $\begin{array}{l}\text { Satisfied } \\
\text { teams }\end{array}$ & $\begin{array}{l}\text { Satis-fied } \\
\text { teams }\end{array}$ \\
\hline Digitalisa & & $\begin{array}{l}\text { Less } \\
\text { trafic, } \\
\text { more } \\
\text { woods }\end{array}$ & $\begin{array}{l}\text { Less } \\
\text { trafic, } \\
\text { more } \\
\text { woods }\end{array}$ & Better life & Better life & $\begin{array}{l}\text { More time, } \\
\text { higher } \\
\text { security }\end{array}$ & $\begin{array}{l}\text { More time, } \\
\text { higher } \\
\text { security }\end{array}$ & $\begin{array}{l}\text { More time, } \\
\text { more } \\
\text { money }\end{array}$ & $\begin{array}{l}\text { Better life } \\
\text { for team }\end{array}$ \\
\hline
\end{tabular}

\section{CONCLUSIONS AND DISCUSSION}

The biggest obstacle for young people to become creative in their home village, according to a survey, is the lack of appreciation of adults for them. Therefore, we have developed a concept of a cooperative trusting environment for the development of creativity, which contributes to the design of a cooperative network under the leadership of an information manager with knowledge of IT, sociology and business administration. In order to be able to implement creative ideas and thereby increase innovation in rural areas, companies, citizens and administrations will join forces in the network to implement some of the prioritized ideas. As a side effect, attractive jobs are created and maintained. The rural life will be alive again!

Acknowledgement. About 350 students of the University of Applied Sciences Trier have worked on these projects between 2015 2019. They have analysed the behaviour of young peoples in rural area EIFEL nearby Trier, they have held some workshops on the introduction of e-car sharing in rural areas or on changes in behaviour through digitalization and meetings of varieties of people, and they have written four books.

\section{REFERENCES}

1. Balzet H. 1997, Unternehmensmodellierung, Kap 9., Lehrbuch der Software-Technik, (in English: enterprise modelling, chap.9, Software techniques, volume 2, Software-Management, Software-Qualitätssicherung und Unternehmensmodellierung (in English: Software management, software quality assurance and enterprise modelling) Spektrum Akademischer Verlag, Heidelberg.

2. Balzert H. 2009. Textbook of Software Engineering: Basic Concepts and Requirements Engineering, Spektrum Akademischer Verlag, Heidelberg.

3. Becker, S. et all. 2019, Innovation an einer Hochschule, Semesterprojekt (in English: Innovation at an university, semester project) IT-Management, Master Business Management, internal paper, university of applied sciences.

4. BMBF Bioeconomy 2019. Last updated on 10.09.2019 FONA, https://www.fona.de/en/topics/biooekonomie-biobasedeconomy.php (accessed on 11/09/2019)

5. BVA 2010. Rollenmodell (in English: Role model) Kap.4 in V-XT-Modell, https://www.cio.bund.de/Web/DE/Architekturenund-Standards/V-Modell-XT/vmodell_xt_node.html (accessed on 13/04/2014) 
6. Diethelm G. et all. 2018, Organisation und Informationsmanagement - Einfluss und Erfolg durch Digitalisierung (in English: Influence and success through digitization), Eduard Maier (HRSG), Verlag Blechschachtel, Edition Glasperle, Karlsruhe.

7. Ehl, L. et all. 2019, Veränderungen in der Unternehmensorganisation unter dem Aspekt der Kooperation - Von interner Organisation zur externen Interaktion (in engish: Changes in business organization in terms of cooperation - from internal organization to external interaction), Eduard Maier (HRSG), Verlag Blechschachtel, Edition Glasperle, Karlsruhe.

8. Happ, C. et all, 2016., Kommunikationsmanagement Volume I, Eduard Maier (HRSG), Verlag Blechschachtel, Edition Glasperle, Karlsruhe.

9. IEEE 1471, 2000. IEEE Recommended Practice for Architectural Description for Software-Intensive Systems https://standards.ieee.org/standard/1471-2000.html (accessed on 04/05/2017)

10. Kücüköz, E., Kuhn E.2018, Kommunikationsmanagement Volume II, - Anforderungen an den Umgang mit Information (in English: Requirements for the handling of information), Eduard Maier (HRSG), Verlag Blechschachtel, Edition Glasperle, Karlsruhe.

11. Kuhn E. 2018. Digitalization slides 10-11, in: Communication skills in the age of digitalization, Speech on the 14. Management conference, Siedlce.

12. Kuhn, E. 2019. Implementation of IT Governance: How Can a Common IT Strategy Create a Cooperation Network? In Štrukelj, T., Mulej, M., O'Sullivan, G. (Eds.): Social Responsibility and Corporate Governance. Volume 1: Preconditions for Integration (forthcoming). London: Palgrave Macmillan.

13. Kuhn E., Küstner H. 2019. My country - my home - my village", (in english: S.72 ff, in Campino 1, 2019, https://www.hochschuletrier.de/hochschule/aktuelles/publikationen/campino/ (accessed on 05/08/2019)

14. Kuhn E. 2019. Characteristics of antifragile management, slides $23 \mathrm{ff}$, in Decision and Change Management, Workshop SNSPA, Bukarest,

15. Lorenz M. et all. 2019,Antifragile Project Management Slides 4-6, in .Mein Land - Meine Heimat - Mein Dorf, Verhindern der Abwanderung von Jugendlichen aus dem Dorf - Rahmenkonzept des Informationsmanagements (IM) in english: My Country My Homeland - My village, preventing the exodus of young people from the village - Framework for Information Management (IM)) , Projekt Informationsmanagement WS 2018/19, Master Wirtschaftsinformatik, Presentation on university.

16. Taleb N.N. 2012. Antifragile: Things That Gain From Disorder, Random House, United States.

17. Tappel T. 2016. Lernumgebung LIVECode, https://www.heise.de/download/product/livecode-61159 (accessed on 04/02/2019)

18. Wising V. 2019. Erster Kongress zum Unternehmertum in der Kultur- und Kreativwirtschaft, (in English: First Congress on Entrepreneurship in the Cultural and Creative Industries) https://isb.rlp.de/home/detailansicht/erster-kongress-zumunternehmertum-in-der-kultur-und-kreativwirtschaft.html (accessed on 06/07/2019)

19. Wojda F. 2006. Innovative Kooperationsmerkmale p. 7 ff, in Innovative Kooperationsnetzwerke, (in engish: Innovative cooperation features p. 7 ff, in Innovative Cooperation Networks), Business \& Management, Schriftenreihe der Hochschulgruppe für Arbeits- und Betriebsorganisation, TU Wien. https://doi.org/10.1007/978-3-8350-9307-2

20. World Café Community Foundation, 2019. The World Cafe: Shaping Our Futures Through Conversations That Matter http://www.theworldcafe.com/key-concepts-resources/world-cafe-method/ (accessed on 08/08/2019)

21. YouTube, 2016. Kostenlose App-Erstellung, CLICKYourAPP, clickyourapp.de (accessed on 04/02/2019) 